\title{
USING SIMULATION TO EVALUATE AND IMPROVE THE THERMAL PERFORMANCE OF COURTYARD OFFICE BUILDINGS IN CAIRO
}

\author{
Essam S. Abdelmagid, \\ Lecturer Assistant ${ }^{1}$
}

E. Marghany, and

Univ. Prof. Assistant ${ }^{1}$
A. Mahdavi,

Univ. Prof. Director ${ }^{2}$

K. Orehounig

Lecturer Assistant ${ }^{2}$

1) Department of Architecture, Assiut University, Assiut, Egypt

2) Department of Building Physics and Building Ecology, Vienna

University of Technology, Vienna, Austria

(Received February 9, 2009 Accepted May 5, 2009)

This paper explores the implications of alternative design options for the thermal performance of office buildings in Cairo, Egypt. Typical courtyard office floor plan was selected for the investigation. Multiple design alternatives were considered involving various glazing and shading types, shading schedules, thermal insulation options, orientations, and ventilation scenarios. A numeric thermal simulation application was used to model the performance of these alternatives parametrically*1. The results show the significant degree to which design measures could reduce cooling requirements of (and overheating tendencies in) courtyard office buildings in Cairo.

\section{INTRODUCTION}

Required cooling loads for office buildings in Cairo, Egypt represent a growing burden for both the environment and the economy. In many instances, the design and construction of these buildings is not preceded with a detailed analysis and evaluation of thermally relevant features and options related to orientation, envelope, glazing ratio, shading devices, and thermal mass $* *$.

In this context, the present contribution explores the implications of various alternative design options in view of the thermal performance (cooling requirements, overheating tendencies) of office buildings in Cairo. Three typical office floor plans were selected for the investigation. Multiple design alternatives were considered involving various glazing and shading types, shading schedules, insulation scenarios (for the opaque parts of the envelope), orientations, and ventilation scenarios. A

[*]TAS (Thermal Analysis Software) is at the forefront of energy simulation software. TAS has the ability to provide a 3 dimensional analysis and profile of the building incorporating all sitting, envelope and interior features The program has the unique capability of accurately modeling non-conventional, energy efficient and creative design solutions such as: Cooling and heating load, External Shading/Overhangs, Daylighting (used with Lightscape), Shade Analysis, Natural Ventilation.

www.edsl.net

[**] tables 1 and 4 include descriptions for all codes used in this context. 
numeric thermal simulation application was used to model the performance of these alternatives parametrically. Simulation results were expressed in terms of annual cooling loads (active building operation scenario) and overheating hours (passive building operation scenario). The results show the significant degree to which design measures could reduce cooling requirements of (and overheating tendencies in) office buildings in Cairo.

\section{APPROACH}

Parametric simulation was selected as a mean of comparing the thermal performance of a number of building design options. The objective was to identify those building design and operation alternatives that would reduce the cooling requirements and overheating tendencies of office buildings in the climatic context of Cairo. An overview of all considered options is provided in Table 1. Based on a preliminary study of typical (contemporary) office floors in Cairo, a square plan with an internal courtyard (SC), (35 by $35 \mathrm{~m}$ ) was selected for this study. Eight zones were considered (four internal perimeter zones and four external perimeter zones) as illustrated in Figure 1. Five glazing options were considered $\left(\mathrm{G}_{0.50}, \mathrm{G}_{0.37}, \mathrm{G}_{0.29}, \mathrm{G}_{0.20}, \mathrm{G}_{0.16}\right)$ and two options for the opaque part of the façade (non-insulated $\mathrm{I}_{0}$ versus insulated $\mathrm{I}_{5}$ ).

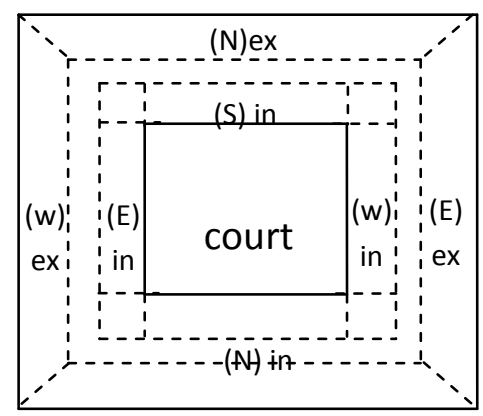

(S) ex
Figure 1. Schematic illustration of the selected floor plan layout (SC), (35 by $35 \mathrm{~m}$ )

Three Blind types were considered, namely internal $\mathrm{BT}_{\mathrm{i}}$, interstitial $\mathrm{BT}_{\mathrm{m}}$ (between the panes of the double-glazing system), and external $\mathrm{BT}_{\mathrm{e}}$ (see Figure 2). When deployed, the blinds were considered to be in one of three positions, namely fully closed $\mathrm{BP}_{\mathrm{C}}$, horizontal $\mathrm{BP}_{\mathrm{H}}$, or at an angle of 30 degrees above horizon $\mathrm{BP}_{\mathrm{S}}$ (see Figure 3). Three blind operation schedules were considered, namely a static (continuously deployed) one $\left(\mathrm{BS}_{\mathrm{F}}\right)$ and two dynamic ones $\left(\mathrm{BS}_{\mathrm{D} 1}, \mathrm{BS}_{\mathrm{D} 2}\right)$, where the deployment schedule was a function of the orientation (see Table 1).
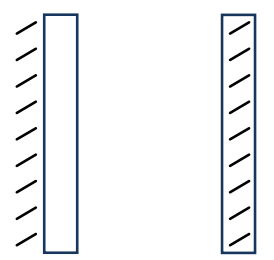

Figure 2. Blind types. Left: exterior $\left(\mathrm{BT}_{\mathrm{e}}\right)$, middle: interstitial $\left(\mathrm{BT}_{\mathrm{m}}\right)$, right: interior $\left(\mathrm{BT}_{\mathrm{i}}\right)$.
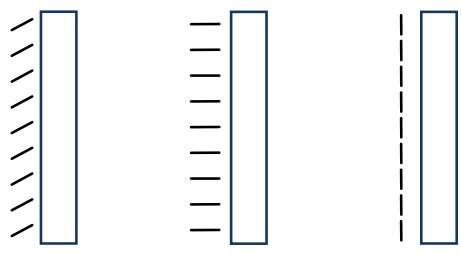

Figure 3. Blind positions. Left: 30 degrees $\left(\mathrm{BP}_{\mathrm{S}}\right)$, middle: horizontal $\left(\mathrm{BP}_{\mathrm{H}}\right)$, right: closed $\left(\mathrm{BP}_{\mathrm{C}}\right)$. 
Five ventilation (air exchange by mechanical fans) schemes were considered initially. However, after a set of preparatory simulation runs, the ventilation schemes were reduced to two. One ventilation scheme was used in the computation of the cooling loads $\left(\mathrm{V}_{1}\right)$ and the other in the computation of overheating $\left(\mathrm{V}_{2}\right)$. Note that the latter ventilation scheme $\left(\mathrm{V}_{2}\right)$ implies increased night-time ventilation via operable windows (see Table 1).

The total internal gains for people, lights, and equipment were considered to be $8 \mathrm{~W} . \mathrm{m}^{-2}$ during the unoccupied hours. Total people and equipment load was considered to be $29 \mathrm{~W} . \mathrm{m}^{-2}$ during the occupied hours (from 8:00 to 18:00). The assumption pertaining to lighting load during the occupied hours was dependent on the blind position and glazing type. It was assumed to be $12 \mathrm{~W} \cdot \mathrm{m}^{-2}$ for fully closed blind positions $\left(\mathrm{BP}_{\mathrm{C}}\right)$ and the cases involving the glazing type $\mathrm{G}_{0.16}$ (with a visible transmittance $\tau_{v}=0.2$ ). Otherwise, it was assumed to be zero W. $\mathrm{m}^{-2}$ for the (SC) option.

Table 1. Overview of the options pertaining to façade insulation, glazing, shading (type, position, and schedule), and ventilation

\begin{tabular}{|c|c|c|}
\hline Parameter & Code & Description \\
\hline Floor plan & $\mathrm{SC}$ & Square plan with courtyard ( 35 x 35 m) \\
\hline \multirow{2}{*}{$\begin{array}{l}\text { Floor } \\
\text { construction } \\
\text { (F) }\end{array}$} & $\mathrm{F}_{\mathrm{W}}$ & Primary floor construction (without carpet and acoustic ceiling) \\
\hline & $\mathrm{F}_{\mathrm{CA}}$ & Primary floor construction with $1 \mathrm{~cm}$ carpet and suspended acoustic ceiling \\
\hline \multirow{2}{*}{$\begin{array}{l}\text { Façade } \\
\text { insulation (I) }\end{array}$} & $\mathrm{I}_{0}$ & Without insulation $\left(\mathrm{U}=2.1 \mathrm{~W} \cdot \mathrm{m}^{-2} \mathrm{~K}^{-1}\right)$ For all facades \\
\hline & $\mathrm{I}_{5}$ & With $5 \mathrm{~cm}$ insulation $\left(\mathrm{U}=0.5 \mathrm{~W} \cdot \mathrm{m}^{-2} \mathrm{~K}^{-1}\right)$ For all facades \\
\hline \multirow{5}{*}{$\begin{array}{l}\text { Glazing } \\
\text { (G) }\end{array}$} & $\mathrm{G}_{0.50}$ & Double glazing; $\mathrm{g}=0.5 ; \tau_{\mathrm{v}}=0.75 ; \mathrm{U}=1.8 \mathrm{~W} \cdot \mathrm{m}^{-2} \mathrm{~K}^{-1}$ \\
\hline & $\mathrm{G}_{0.37}$ & Single glazing; $\mathrm{g}=0.37 ; \tau_{\mathrm{v}}=0.40 ; \mathrm{U}=5.7 \mathrm{~W}^{-2} \mathrm{~K}^{-1}$ \\
\hline & $\mathrm{G}_{0.29}$ & Double glazing; $\mathrm{g}=0.29 ; \tau_{\mathrm{v}}=0.42 ; \mathrm{U}=1.8 \mathrm{~W} \cdot \mathrm{m}^{-2} \mathrm{~K}^{-1}$ \\
\hline & $\mathrm{G}_{0.20}$ & Single glazing; $\mathrm{g}=0.20 ; \tau_{\mathrm{v}}=0.50 ; \mathrm{U}=5.7 \mathrm{~W} \cdot \mathrm{m}^{-2} \cdot \mathrm{K}^{-1}$ \\
\hline & $\mathrm{G}_{0.16}$ & Single glazing; $\mathrm{g}=0.16 ; \tau_{\mathrm{v}}=0.20 ; \mathrm{U}=5.7 \mathrm{~W} \cdot \mathrm{m}^{-2} \mathrm{~K}^{-1}$ \\
\hline \multirow{3}{*}{$\begin{array}{l}\text { Blind } \\
\text { Types } \\
\text { (BT) }\end{array}$} & $\mathrm{BT}_{\mathrm{i}}$ & Internal blinds \\
\hline & $\mathrm{BT}_{\mathrm{m}}$ & Interstitial blinds \\
\hline & $\mathrm{BT}_{\mathrm{e}}$ & External blinds \\
\hline \multirow{3}{*}{$\begin{array}{l}\text { Blind } \\
\text { Position } \\
\text { (BP) }\end{array}$} & $\mathrm{BP}_{\mathrm{C}}$ & Fully closed \\
\hline & $\mathrm{BP}_{\mathrm{H}}$ & Horizontal \\
\hline & $\mathrm{BP}_{\mathrm{S}}$ & At an angle of 30 degrees above horizon \\
\hline \multirow{3}{*}{$\begin{array}{l}\text { Blinds } \\
\text { deployment } \\
\text { Schedule } \\
\text { (BS) }\end{array}$} & $\mathrm{BS}_{\mathrm{F}}$ & Continuous deployment \\
\hline & $\mathrm{BS}_{\mathrm{D} 1}$ & $\begin{array}{l}\text { South: 8:00 to } 16: 00\left(\mathrm{BP}_{\mathrm{C}}\right) \text {; } \\
\text { East: from 6:00 to } 12: 00\left(\mathrm{BP}_{\mathrm{C}}\right) \text {; } \\
\text { West: from 12:00 to 8:00 }\left(\mathrm{BP}_{\mathrm{C}}\right)\end{array}$ \\
\hline & $\mathrm{BS}_{\mathrm{D} 2}$ & $\begin{array}{l}\text { South: 8:00 to } 16: 00\left(\mathrm{BP}_{\mathrm{C}}\right), 16: 00 \text { to } 8: 00\left(\mathrm{BP}_{\mathrm{S}}\right) \\
\text { East: from 6:00 to } 12: 00\left(\mathrm{BP}_{\mathrm{C}}\right), 12: 00 \text { to } 6: 00\left(\mathrm{BP}_{\mathrm{S}}\right) \text {; } \\
\text { West: from 12:00 to } 8: 00\left(\mathrm{BP}_{\mathrm{C}}\right), 8: 00 \text { to } 12: 00\left(\mathrm{BP}_{\mathrm{S}}\right)\end{array}$ \\
\hline \multirow{2}{*}{$\begin{array}{l}\text { Ventilation (by } \\
\text { mechanical } \\
\text { fans) }(V)\end{array}$} & $\mathrm{V}_{1}$ & $\begin{array}{l}\text { Summer }-8: 00 \text { to } 18: 00,2 \mathrm{ACH} ; 18: 00 \text { to } 8: 00,2 \mathrm{ACH} \text {; Winter }-8: 00 \text { to } 18: 00,4 \mathrm{ACH} \text {; } \\
18: 00 \text { to } 8: 00,2 \mathrm{ACH}\end{array}$ \\
\hline & $\mathrm{V}_{2}$ & $\begin{array}{l}\text { Summer - 7:00 - 12:00, } 2 \text { ACH; 12:00 - 16:00, } 1 \text { ACH; 16:00 - 24, } 2 \text { ACH; 24:00 - 7:00, } 10 \\
\text { ACH }\end{array}$ \\
\hline
\end{tabular}

The glazing area was assumed to constitute in all cases $38 \%$ of the total façade area. The assumption pertaining to the primary floor construction was based on the 
current practice in Egypt involving the following layers: floor carpet $(1 \mathrm{~cm})$ floor tiles $(2 \mathrm{~cm})$, mortar $(2 \mathrm{~cm})$, sand $(6 \mathrm{~cm})$, concrete slab $(15 \mathrm{~cm})$, air space $(20 \mathrm{~cm})$, acoustic tiles $(1 \mathrm{~cm})$. This default floor construction assumption $\left(\mathrm{F}_{\mathrm{CA}}\right.$ in Table 1$)$ was used while simulating cooling loads (active building operation scenario). However, for the simulation of the overheating (passive building operation scenario), the construction was simulated without the carpet and the acoustic tiles layers $\left(\mathrm{F}_{\mathrm{W}}\right.$ in Table 1$)$ to ensure a better coupling of the thermal mass of the floor construction to simulated office zones.

Altogether 40 scenarios (different combinations of options given in Table 1) were simulated, i.e. 40 scenarios for SC floor plan option. To illustrate these scenarios, Table 2 lists the 20 configurations (used in computation of cooling loads) and the alternative floor construction $\left(\mathrm{F}_{\mathrm{W}}\right)$ is specified in a similar manner.

Table 2. Overview of the 20 simulation scenarios for SC (Square plan with courtyard, $35 \times 35 \mathrm{~m}$ ), FCA (floor construction with carpet and acoustic ceiling), and $\mathrm{V}_{1}$ ventilation scenario

\begin{tabular}{llllll}
\hline SCENARIO & INSULATION & GLAZING & SHADES & $\begin{array}{l}\text { BLIND } \\
\text { POSITION }\end{array}$ & $\begin{array}{l}\text { SHADING } \\
\text { SCHEDULE }\end{array}$ \\
\hline 1 & $\mathrm{I}_{0}$ & $\mathrm{G}_{0.5}$ & - & - & - \\
\hline 2 & $\mathrm{I}_{0}$ & $\mathrm{G}_{0.5}$ & $\mathrm{BT}_{\mathrm{i}}$ & $\mathrm{BP}_{\mathrm{C}}$ & $\mathrm{BS}_{\mathrm{D} 1}$ \\
\hline 3 & $\mathrm{I}_{0}$ & $\mathrm{G}_{0.5}$ & $\mathrm{BT}_{\mathrm{m}}$ & $\mathrm{BP}$ & $\mathrm{BS}_{\mathrm{D} 1}$ \\
\hline 4 & $\mathrm{I}_{0}$ & $\mathrm{G}_{0.5}$ & $\mathrm{BT}_{\mathrm{e}}$ & $\mathrm{BP}_{\mathrm{C}}$ & $\mathrm{BS}_{\mathrm{D} 1}$ \\
\hline 5 & $\mathrm{I}_{0}$ & $\mathrm{G}_{0.5}$ & $\mathrm{BT}_{\mathrm{e}}$ & $\mathrm{BP}_{\mathrm{S}} / \mathrm{BP}_{\mathrm{C}}$ & $\mathrm{BS}_{\mathrm{D} 2}$ \\
\hline 6 & $\mathrm{I}_{0}$ & $\mathrm{G}_{0.5}$ & $\mathrm{BT}_{\mathrm{e}}$ & $\mathrm{BP}_{\mathrm{S}}$ & $\mathrm{BS}_{\mathrm{F}}$ \\
\hline 7 & $\mathrm{I}_{0}$ & $\mathrm{G}_{0.5}$ & $\mathrm{BT}_{\mathrm{e}}$ & $\mathrm{BP}_{\mathrm{H}}$ & $\mathrm{BS}_{\mathrm{F}}$ \\
\hline 8 & $\mathrm{I}_{0}$ & $\mathrm{G}_{0.37}$ & - & - & - \\
\hline 9 & $\mathrm{I}_{0}$ & $\mathrm{G}_{0.29}$ & - & - & - \\
\hline 10 & $\mathrm{I}_{0}$ & $\mathrm{G}_{0.2}$ & - & - & - \\
\hline 11 & $\mathrm{I}_{0}$ & $\mathrm{G}_{0.2}$ & $\mathrm{BT}_{\mathrm{e}}$ & $\mathrm{BP}_{\mathrm{C}}$ & $\mathrm{BS}_{\mathrm{D} 1}$ \\
\hline 12 & $\mathrm{I}_{0}$ & $\mathrm{G}_{0.2}$ & $\mathrm{BT}_{\mathrm{e}}$ & $\mathrm{BP}_{\mathrm{S}} / \mathrm{BP}_{\mathrm{C}}$ & $\mathrm{BS}_{\mathrm{D} 2}$ \\
\hline 13 & $\mathrm{I}_{0}$ & $\mathrm{G}_{0.2}$ & $\mathrm{BT}_{\mathrm{e}}$ & $\mathrm{BP}_{\mathrm{S}}$ & $\mathrm{BS}_{\mathrm{F}}$ \\
\hline 15 & $\mathrm{I}_{5}$ & $\mathrm{G}_{0.5}$ & $\mathrm{BT}_{\mathrm{e}}$ & $\mathrm{BP}_{\mathrm{C}}$ & $\mathrm{BS}_{\mathrm{D} 1}$ \\
\hline 16 & $\mathrm{I}_{5}$ & $\mathrm{G}_{0.5}$ & $\mathrm{BT}_{\mathrm{e}}$ & $\mathrm{BP}_{\mathrm{S}} / \mathrm{BP}_{\mathrm{C}}$ & $\mathrm{BS}_{\mathrm{D} 2}$ \\
\hline 17 & $\mathrm{I}_{5}$ & $\mathrm{G}_{0.5}$ & $\mathrm{BT}_{\mathrm{e}}$ & $\mathrm{BP}_{\mathrm{S}}$ & $\mathrm{BS}_{\mathrm{F}}$ \\
\hline 18 & $\mathrm{I}_{5}$ & $\mathrm{G}_{0.2}$ & $\mathrm{BT}_{\mathrm{e}}$ & $\mathrm{BP}_{\mathrm{C}}$ & $\mathrm{BS}_{\mathrm{D} 1}$ \\
\hline 19 & $\mathrm{I}_{5}$ & $\mathrm{G}_{0.2}$ & $\mathrm{BT}_{\mathrm{e}}$ & $\mathrm{BP}_{\mathrm{S}} / \mathrm{BP}_{\mathrm{C}}$ & $\mathrm{BS}_{\mathrm{D} 2}$ \\
\hline 20 & $\mathrm{I}_{5}$ & $\mathrm{G}_{0.2}$ & $\mathrm{BT}_{\mathrm{e}}$ & $\mathrm{BP}_{\mathrm{S}}$ & $\mathrm{BS}_{\mathrm{F}}$ \\
\hline & $\mathrm{I}_{0}$ & $\mathrm{G}_{0.16}$ & - & - & - \\
\hline
\end{tabular}

Simulations were performed using a numeric thermal simulation application (EDSL 2008) ${ }^{(1)}$. The input information concerning Cairo's climate was based on a reference year weather file (METEOTEST 2008) ${ }^{(2)}$.

[1] EDSL 2008. A-TAS Version 8.5. Environmental Design Solutions Limited. www.edsl.net. [2] Meteotest 2008. Meteonorm version 6.0. www.meteotest.ch. 
Two kinds of simulations were performed: i) Simulation of cooling loads (active building operation assumption), ii) Mean overheating (free-running building operation assumption). The thermostat settings (for the calculation of cooling loads) were assumed to be 21 to $25{ }^{\circ} \mathrm{C}$ (for occupied hours) As a mean annual value for thermal comfortable temperature and 16 to $30{ }^{\circ} \mathrm{C}$ (for unoccupied hours) to keep the internal environment suitable for living

For the computation of the mean overheating $\left(\mathrm{OH}_{\mathrm{m}}\right)$, the following definition was used:

$$
O H_{m}=\sum_{j=1}^{n} \frac{\theta_{i, j}-\theta_{r}}{n}
$$

Where $\theta_{\mathrm{i}, \mathrm{j}}$ denotes mean indoor air temperature $\left({ }^{\circ} \mathrm{C}\right)$ at hour $\mathrm{j}$ (averaged over all simulated office zones in the floor), $\theta_{\mathrm{r}}$ the reference indoor air temperature for overheating $\left({ }^{\circ} \mathrm{C}\right)$, and $n$ the total number of occupied office hours over the course of the simulation period (from May $1^{\text {st }}$ to October $31^{\text {st }}$ ). Note that the term $\theta_{i, j}-\theta_{r}$ was considered only for those hours when $\theta_{i, j}>\theta_{r}$.

Mean overheating $\left(\mathrm{OH}_{\mathrm{m}}\right)$ was computed for four different sets of assumptions pertaining to the applicable values for the reference overheating temperature $\theta_{r}$. The first set is based on a constant reference overheating temperature of $26^{\circ} \mathrm{C}$. The second set uses the concept of Neutrality Temperature ${ }^{(3)}$ which is derived as a function of the mean monthly outdoor air temperature. The third set assumes, in addition, a fan-induced air flow speed of about $1 \mathrm{~m} \cdot \mathrm{s}^{-1}$ at the workstations. The fourth set is similar to the third, with the exception that the air flow speed is assumed to be $1.5 \mathrm{~m} \cdot \mathrm{s}^{-1(4)}$. These four cases are summarized in Table 3.

Table 3. The four value sets for the reference overheating temperature $\square_{\mathrm{r}}$ (in ${ }^{\circ} \mathrm{C}$ )

\begin{tabular}{lllll}
\hline Set & 1 & 2 & 3 & 4 \\
\hline May & 26.0 & 27.9 & 31.7 & 33.0 \\
\hline June & 26.0 & 28.6 & 32.4 & 33.7 \\
\hline July & 26.0 & 28.8 & 32.6 & 33.9 \\
\hline August & 26.0 & 28.7 & 32.5 & 33.8 \\
\hline September & 26.0 & 28.2 & 32.0 & 33.3 \\
\hline October & 26.0 & 27.5 & 31.3 & 32.6 \\
\hline
\end{tabular}

\section{RESULTS}

The Figure from 4 to 9 shows the simulated annual cooling load (in $\mathrm{kWhm}^{-2} \cdot \mathrm{a}^{-1}$ ) and cooling load reductions (in percentage) for the 20 scenarios as specified in Table 2. Figure 10 to 12 shows the mean overheating for the previously mentioned four

[3] Auliciems, A. 1981. Towards a psycho-physiological model of thermal perceptions. Int. J. of Biometeorology 25:109-122..

[4] Szokolay, S. V. 2004. Introduction to Architectural Science. Architectural Press. Elsevier. ISBN 0750658495. 
assumption sets pertaining to the values of the underlying reference overheating temperature $\left(\theta_{r}\right)$ as per Table 3 .

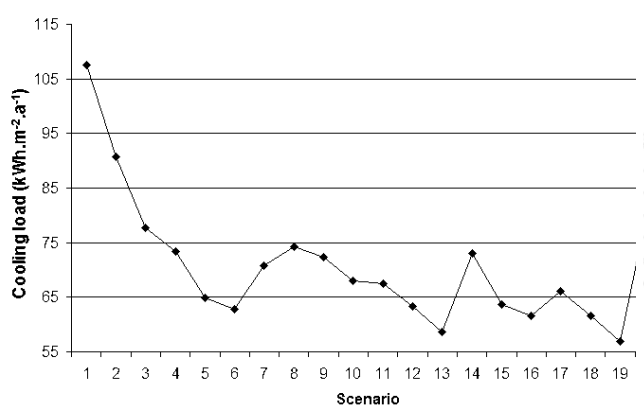

Figure 4. Simulated annual cooling load (in $\mathrm{kWh}^{-2} \mathrm{a}^{-1}$ ) for the 20 scenarios (see Table 2) for the floor plan options SC (Ventilation scheme: $\mathrm{V}_{1}$, floor construction: $\left.\mathrm{F}_{\mathrm{CA}}\right)$.

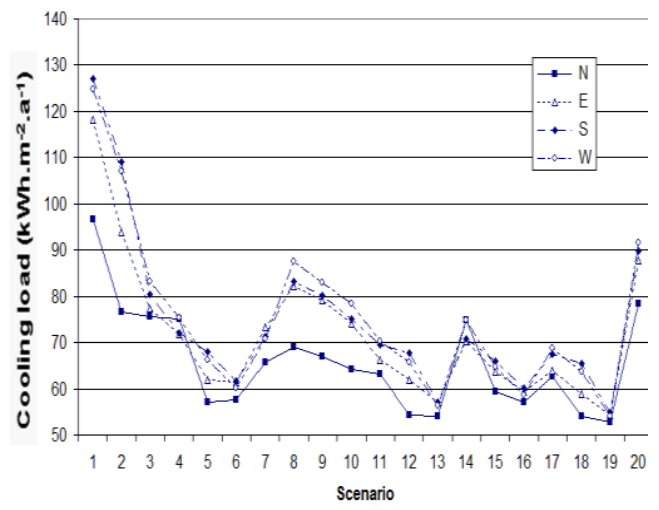

Figure 6. Simulated annual cooling for the four external perimeter zones of the floor plan options SC (Ventilation scheme: $\mathrm{V}_{1}$, floor construction: $\left.\mathrm{F}_{\mathrm{CA}}\right)$.

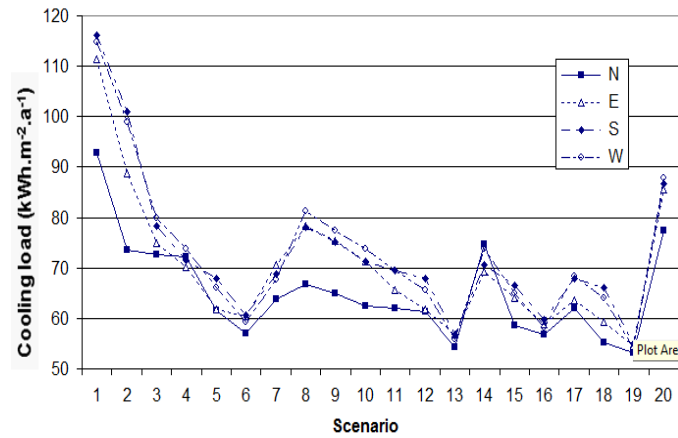

Figure 8. Simulated annual cooling for the four internal perimeter zones of the floor plan options SC (Ventilation scheme: $\mathrm{V}_{1}$, floor construction: $\left.\mathrm{F}_{\mathrm{CA}}\right)$.

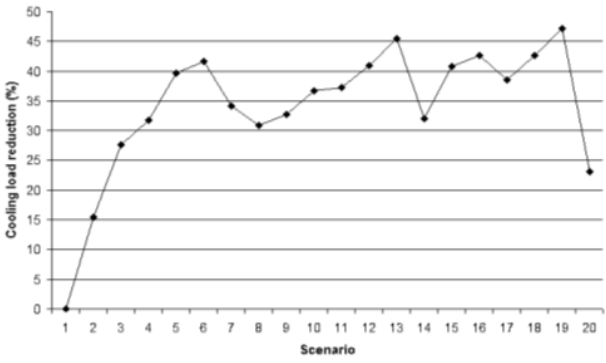

Figure 5. Simulated cooling load reduction for the 20 scenarios (see Table 2) and the floor plan option $\mathrm{SC}$ (Ventilation scheme: $\mathrm{V}_{1}$, floor construction: $\left.\mathrm{F}_{\mathrm{CA}}\right)$.

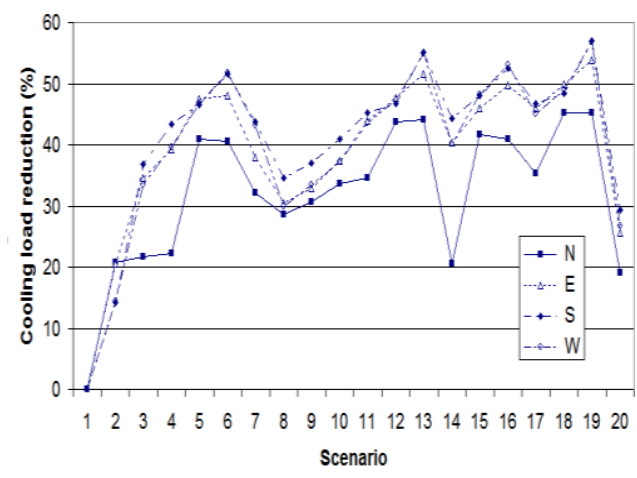

Figure 7. Simulated cooling load reduction for the four external perimeter zones of the floor plan options SC (Ventilation scheme: $\mathrm{V}_{1}$, floor construction: $\left.\mathrm{F}_{\mathrm{CA}}\right)$.

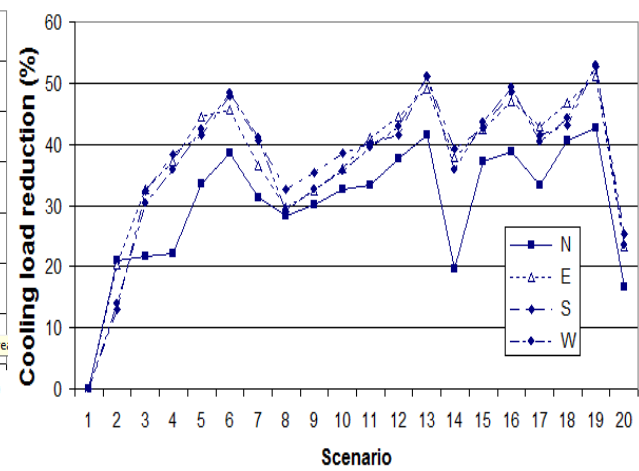

Figure 9. Simulated cooling load reduction for the four internal perimeter zones of the floor plan options SC (Ventilation scheme: $\mathrm{V}_{1}$, floor construction: $\left.\mathrm{F}_{\mathrm{CA}}\right)$. 


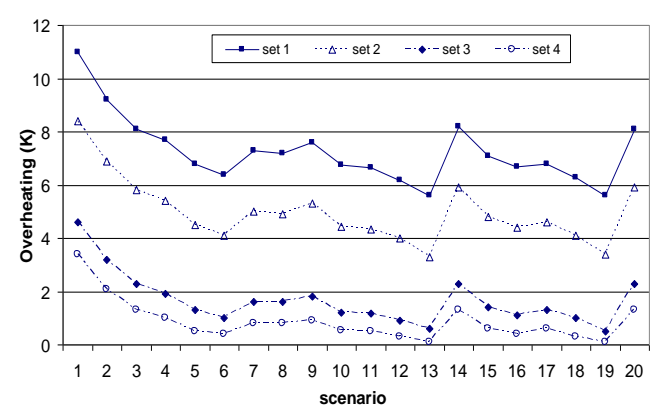

Figure 10. Mean overheating (in K) for 20 scenarios (Table 2), for floor plan options $\mathrm{SC}$, Ventilation scheme $\mathrm{V}_{2}$, floor construction $\mathrm{F}_{\mathrm{W}}$, and four assumption sets regarding reference overheating temperature $\left(\theta_{r}\right)$ as per Table 3 .

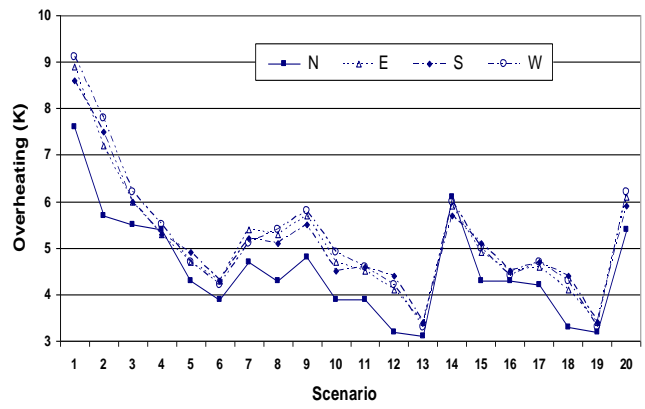

Figure 11. Mean overheating (in K) for 20 scenarios (Table 2), four external perimeter zones, set 2 (reference overheating temperature as per Table 3), floor plan options SC, Ventilation scheme $\mathrm{V}_{2}$, floor construction $\mathrm{F}_{\mathrm{W}}$

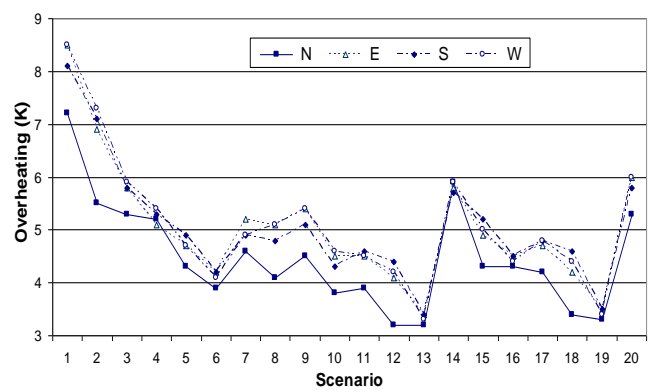

Figure 12. Mean overheating (in K) for 20 scenarios (Table 2), four internal perimeter zones (N, E, $\mathrm{S}, \mathrm{W}$ ), set 2 (reference overheating temperature as per Table 3), floor plan options SC, Ventilation scheme $\mathrm{V}_{2}$, floor construction $\mathrm{F}_{\mathrm{W}}$

\section{DISCUSSION}

The results of the above described parametric simulation study allow for a number of inferences:

- The cooling load reduction potential of many of the scenarios considered is significant (Figure 4). Through a combination of buildings' features, cooling load reductions of about $45 \%$ for the SC floor plan option, see scenarios 13 and 19 (as compared to a base case starting scenario) appear feasible (see Figure 5). The better performance of the scenario 13 and 19 compared to the other scenarios is mainly due to the usage of the external blind in slopping position (At an angle of 30 degrees above horizon) and glazing type with small solar transmittance value $\mathrm{G}_{0.20}$ (Single glazing; $\mathrm{g}=0.20 ; \tau_{\mathrm{v}}=$ $0.50 ; \mathrm{U}=5.7 \mathrm{~W} \cdot \mathrm{m}^{-2} \cdot \mathrm{K}^{-1}$ )

The existence and deployment of external shades is a key ingredient of all better performing scenarios: the top eight performing scenarios amongst the 20 scenarios considered include external blinds ( $\mathrm{BT}_{\mathrm{e}}$, Table 1 and Figure 2). The better performance of the external blinds due to the usage of the external Blinds stop solar radiation before it enters the room. The angled position of the blind $\left(\mathrm{BP}_{\mathrm{S}}\right.$, 
Table 1 and Figure 3) contributes to a higher performance, mainly due to partial daylight usage and the respective (assumed) lower electrical lighting load.

- Cooling loads are higher and overheating tendencies are more pronounced in offices with west orientation (see Figures $6,8,11,12$ ). Consequentially, the improvement effect (relative cooling load reduction in \%) of various alternative scenarios is more visible for offices facing west (see Figure 7, 9).

- Glazing with higher shading effectiveness (a low g-value) contributes to cooling load reduction (see table 1 scenarios 1,8,9,10,20, Figures 4, 5), whereas the glazing U-value does not appear to play a decisive role: glazing type $\mathrm{G}_{0.20}$, which has a low g-value but a high $\mathrm{U}$-value, is frequently represented in the top-ranking scenarios (see Table 1, Figures 4, 6, and 7). As, in this case, the visual transmittance is not too low, daylight usage potential (and thus electrical energy use reduction for lighting) is not compromised.

- Adding insulation to solid parts of the wall has a limited positive effect in reducing cooling loads demand because the heat load of the building is still relatively high and heat can be extracted either by appropriate ventilation or by transmission through the walls. See scenarios 11, 12 and 13 (as compared to scenarios 17, 18 and 19) Figures 4 to 9.

- Alternative improvement scenarios - in the passive operation mode - substantially reduce the mean overheating in the offices (up to about $4 \mathrm{~K}$, depending on scenario and the reference overheating temperature assumption). Though not exactly identical, there is a clear congruence (see Figures 4 and 12) between the ranking of the scenarios in view of lower cooling demand (active operation regime) and lower overheating tendency (passive operation regime). Higher nighttime ventilation rates $\left(\mathrm{V}_{2}\right.$, Table 1, Figures 10 to 12$)$ are a necessary, though not sufficient condition for a significant reduction of the overheating tendency.

- With a few exceptions (see Figure 10, scenarios 13 and 19, SC floor plan option), none of the passive scenarios examined truly eliminates overheating risk. In our simulation-based explorations, mean overheating could be reduced to almost zero $\mathrm{K}$ for floor plan option SC (see Figure 10, scenario 13). But the pertinent underlying overheating reference temperature assumption (set 4 as per Table 3) involves considerable draft discomfort ramifications. In order to effectively minimize overheating tendency under more readily defensible thermal comfort assumptions (e.g. set 2, Table 3), alternative building designs (geometry, layout, construction elements and materials, etc.) must be explored.

\section{CONCLUSION}

The results of an extensive simulation-based study of the thermal performance of typical high-rise office buildings in Cairo, Egypt were presented. It could be demonstrated that, through a combination of design features (particularly glazing and shading solutions and ventilation regimes), a significant reduction of the cooling loads (in an active building operation mode) and overheating tendency (in free-running operation mode) can be achieved. 
Concerning the active building operation mode, given Cairo's predominantly hot dry climate, a combination of radiative (hydronic) cooling and controlled ventilation could be an attractive option.

As far as the potential of a passive operation mode is concerned, given the current building typology and practices, provision of thermally comfortable indoor environment in the summer period represents a difficult challenge. To make such a passive option practically feasible, a number of requirements must be met. These include sufficient thermal mass, effective day-time shading, effective night-time ventilation and cross-ventilation possibility, sufficient room height to allow for stratification, judicious use of air movement inducing fans, etc.). Moreover, rigid low cooling reference temperatures - as applied in the case of air-conditioned offices in affluent countries - would not be a workable option. Rather, flexible thermal comfort requirements (consistent with the implications of the adaptive thermal comfort theory) and a fitting dress code (involving climatically adapted clothing with low clo-values) would have to be considered.

Note that concepts and solutions involving passive cooling strategies frequently encounter criticism involving references to urban noise and air pollution (problematic in view of natural ventilation) and thermal comfort standards that, if not met, would cause major loss of productivity and well-being. In the long run, however, air pollution and noise exposure should be treated as severe environmental problems and not as excuse to indefinitely and hermetically seal the building envelope against "unfiltered" air exchange. Furthermore, given a number of serious globally relevant developments (energy supply and demand dynamics, energy price increase, environmental emissions due to operation of buildings, and climate change, etc.), the applicability of rigid indoor environment standards (constant low indoor temperatures in summer) must be seriously questioned. Instead, creative approaches in architecture and building technology, accompanied with appropriate organizational and cultural (e.g. working hours, clothing practices) need to be part of solution schemes for sustainable and habitable built environments.

\section{REFERENCES}

1. Auliciems, A. 1981. Towards a psycho-physiological model of thermal perceptions. Int. J. of Biometeorology 25:109-122.

2.EDSL 2008. A-TAS Version 8.5. Environmental Design Solutions Limited. www.edsl.net.

3. Meteotest 2008. Meteonorm version 6.0. www.meteotest.ch.

4.Szokolay, S. V. 2004. Introduction to Architectural Science. Architectural Press. Elsevier. ISBN 0750658495. 
Table 4. Descriptions for some codes used in this context.

\begin{tabular}{ll}
\hline $\mathrm{CODE}$ & DESCRIPTION \\
\hline $\mathrm{OH}$ & Overheating \\
\hline $\mathrm{OH}_{\mathrm{m}}$ & Mean overheating \\
\hline $\mathrm{G}$ & solar transmittance \\
\hline$\tau_{\mathrm{v}}$ & lighting transmittance \\
\hline $\mathrm{U}$ & conductance $\mathrm{W} \cdot \mathrm{m}^{-2} \mathrm{~K}^{-1}$ \\
\hline$\theta_{\mathrm{i}, \mathrm{j}}$ & mean indoor air temperature $\left({ }^{\circ} \mathrm{C}\right)$ at hour $\mathrm{j}$ \\
\hline$\theta_{\mathrm{r}}$ & the reference indoor air temperature for overheating \\
\hline $\mathrm{ACH}$ & Air Changes per Hour \\
\hline $\mathrm{K}$ & Kelvin \\
\hline $\mathrm{In}$ & Internal \\
\hline $\mathrm{Ex}$ & External \\
\hline
\end{tabular}

\section{ACKNOWLEDGMENT}

The Austrian Exchange Service ÖAD (Österreicher Austauschdienst) provided Mr. E. Abdelmagid with support towards his research stay at the Department of Building Physics and Building Ecology, Vienna University of Technology, Vienna, Austria.

\section{استخدام المحاكاة في تقيم وتحسين الاداء الحراري للمباني الاداريه ذات الافنيه فى القاهرة}

تعد المباني الإدارية بما تحويه من تجهيزات كهربائية وميكانيكيه مستهلك رئيسي للطاقة، وهو ما دعا معظم دول العالم إلي وضع برامج متخصصة لتوفير الطاقة المستهلكة في هذه النوعية من المباني. تبحث هذه الورقة في تأثير البدائل التصميميه المختلفه على الاداء الحراري للمباني الاداريه ذات الافنيه فى القاهره، تناولت الدراسه نأثثر هذه البدائل التصميميه والتي تشمل عدة أنواع من الزجاج بمواصفات وخصائص مختلفة، التظليل بأشكال متعددة، العزل الحراري والتهوية؛ وذلك باستخدام برنامج محاكاه خاص بالتحليل الحراري للمباني كاداه لدراسة أداء هذه البدائل التصميمية وتأثثرها على استهلاك الطاقة في المبني، وتهدف الدراسة إلى عرض هذه البدائل التصميمه والي اي حد يمكن ان تساهم فى توفير الطاقه اللازمه للتبريد (خفض الحراره الزائده) فى المباني الاداريه ذات الافنيه بالقاهرة وذلك من خلال عدة بدائل تراعي الظروف المناخية للمنطقة محل الدراسة. 